\title{
An assessment of households' perceptions of private security companies and crime in urban Ghana
}

\author{
George Owusu*, Adobea Yaa Owusu, Martin Oteng-Ababio, Charlotte Wrigley-Asante and Isaac Agyapong
}

\begin{abstract}
Amidst the growing incidence of urban crime in Ghana is the proliferation of private security companies (PSCs). As of December 2014, Ghana's Ministry of Interior, responsible for the registration and regulation of PSCs, reported that there were as many as 176 licensed companies in 'good standing' (that is, companies which have renewed their operating licenses) in the country. In broad terms, the proliferation of PSCs reflects a global trend and represents a logical extension of economic liberalization and privatization efforts of the Ghanaian state. The broad proposition in the security literature is that as the state cuts back on public services such as policing and security, the popular doctrine of resilience shifts the burden of security to society and consequently justifying the use of private security organizations. While PSCs have proliferated in recent decades, little studies have been done regarding their conformity with the existing policy, institutional and legal framework that set them up and the public perceptions about their activities and crime prevention in Ghanaian cities. More importantly, the extent to which PSCs have impacted on crime incidence and the public's perceptions on their operations and accessibility remain to be explored. Based on key informant interviews as well as a survey of 2745 households undertaken in key Ghanaian cities (Accra, Kumasi, Sekondi-Takoradi and Tamale), this study seeks to bridge these knowledge gaps by critically examining households' perceptions of PSCs and crime in large Ghanaian metropolitan cities. Quite contrary to the dominant propositions in the literature, the household survey identifies job creation/business as the single most important driver for the proliferation of PSCs.
\end{abstract}

Keywords: Private security companies, Urban crime, Urbanization, Security privatization, Accra, Kumasi, Sekondi-Takoradi, Tamale, Ghana

\section{Background}

Although there are many dimensions of urban crime, studies have indicated its widespread existence in all countries (UN-Habitat 2007). Consequently, crime and violence have received significant attention in the urban literature reflecting its visible presence in cities worldwide, particularly in developing countries where rapid urbanization is occurring within the context of weak governance systems and limited infrastructure and services (including policing) (Graham 2010). Indeed, it is now widely acknowledged that safety and security are structuring forces for cities as

\footnotetext{
*Correspondence: GOwusu@ug.edu.gh; geowusu@yahoo.com Institute of Statistical, Social and Economic Research/Department of Geography and Resource Development, University of Ghana, Legon,
} Ghana they impact on every facet of urban life at the individual, household, community and city levels.

An increasing common response to crime across the world is the privatization of security and the proliferation of private security companies (PSCs). ${ }^{1}$ This is partly as a result of inadequate public policing and, inefficient and ineffective judicial system (Lippert and O'Connor 2003). The proliferation of PSCs is very interesting as the trend

\footnotetext{
${ }^{1}$ Corporate entities operating in the security industry can be described and defined in variety of ways (Percy 2012). However, in this study, PSCs are referred to as private corporate entities established for profit purposes to 'observe, deter, report and record in relation to crime, safety, disorder or emergency' (UNODC 2014, p. 3). These private companies, which the United Nations Office on Drugs and Crime (2014) describes as 'Civilian Private Security Services' provide commercial or fee-paying services aimed at protecting persons and physical assets, particularly in residential areas.
}

\section{Springer Open}


Table 1 Decadal aggregate crime growth and variation in Ghana, 1980-2010

\begin{tabular}{|c|c|c|c|c|c|}
\hline \multirow[t]{2}{*}{ Crime type } & \multicolumn{3}{|c|}{ Decade aggregate } & \multicolumn{2}{|c|}{$\begin{array}{l}\text { Inter-cohort varia- } \\
\text { tions (percentage) }\end{array}$} \\
\hline & 1980-1989 & 1990-1999 & $2000-2010$ & 1980-1999 & $\begin{array}{l}1990- \\
2010\end{array}$ \\
\hline Murder & 3527 & 3473 & 5313 & -2 & 35 \\
\hline Assault & 446,625 & 645,903 & 972,722 & 31 & 34 \\
\hline $\begin{array}{l}\text { Armed } \\
\text { robbery }\end{array}$ & 1848 & 1345 & 12,069 & -37 & 89 \\
\hline Theft & 416,145 & 517,420 & 801,483 & 20 & 35 \\
\hline Narcotics & 228 & 465 & 5481 & 51 & 92 \\
\hline Total & 868,373 & $1,168,606$ & $1,797,068$ & 26 & 93 \\
\hline
\end{tabular}

Source: Ghana Police Service, Crime Statistics Bureau, Accra (Owusu et al. 2015, p. 258)

is observed even among industrialized countries where recent studies have revealed crime drop since the mid1990s, a phenomenon that has bemused many scholars (see Farrell et al. 2010, 2011; Van Dijk et al. 2012). According to the UN-Habitat (2007), almost every city in the world has PSCs and estimates in 2000 indicated that the annual growth of private security was 30 and $8 \%$ in developing and developed countries respectively. The UN-Habitat report notes that the balance between public and private crime prevention is a major issue requiring attention.

In Ghana, a recent report by the Ministry of Interior, revealed that there were as many as 176 licensed companies in 'good standing' as of December 2014 (The Daily Graphic 2014, pp. 24-25). ${ }^{2}$ The report suggests that a number of PSCs are operating without official licenses/ permits. This clearly puts the number of PSCs operating in Ghana beyond what is known by officialdom. The proliferation of PSCs and the operation of unregistered PSCs have been subjects of long discussions, and some have advocated for the effective management of the sector to prevent it from undermining national security in the name of business or profit-making (ASDR 2008; GTUC, FES 2011; Abudu et al. 2013). More importantly, the proliferation of PSCs is occurring within the context of growing levels of reported crime as illustrated in Table 1. The Table shows that reported cases of all crime types in Ghana has risen significantly over the last three decades, particularly for the period, 2000-2010.

PSCs in Ghana provide a range of security services which complement that of the state, notably provision of security and patrol of private residential and institutional buildings (banks, hospitals, schools, markets/shopping

\footnotetext{
${ }^{2}$ Ghana's Ministry of Interior is responsible for the registration and regulation of PSCs in the country, and it defines PSCs in 'good standing' as companies which have renewed their operating licenses up to date.
}

outlets, transport terminals, etc.). ${ }^{3}$ While PSCs have proliferated in recent decades, little studies have been done regarding their conformity with the existing policy, institutional and legal framework and the extent to which they are reconfiguring crime prevention in Ghanaian cities. More importantly, the extent to which PSCs have impacted on crime incidence and the public's perceptions on their operations remained unexplored. Based on key informant interviews as well as a household survey in key Ghanaian cities (Accra, Kumasi, Sekondi-Takoradi and Tamale), this study seeks to bridge these knowledge gaps by examining households' perceptions of PSCs and crime in these cities. In specific terms, the paper has two objectives:

1. Analyze the existing policy, institutional and legal framework regulating PSCs and its implications for crime prevention in urban Ghana and;

2. Examine households' perception of PSCs and the extent to which PSCs are impacting on urban crime.

After the introduction, the article is structured into four sections. The first section deals with the global rise of PSCs and the Ghanaian case while section two looks at the study's methodology. Section three is on the findings focusing on the paper's objectives and the last section ends with the study's conclusions.

\section{Global Rise of PSCs and the Ghanaian Case}

Recent studies indicate that in both developed and developing countries, PSCs have not only increased in numbers but also there has been significant expansion in the services and roles they play, number of staff/personnel employed and estimated worth of the industry (see Table 2). ${ }^{4}$ Besides, studies have shown that the size of individual PSCs has increased drastically as demand for their services soars across the world, allowing PSCs to go global and operate across borders. For instance, UNODC (2014, p. 2) notes that the largest private security company employs over 620,000 staff in over 120 countries and had a turnover of around $\$ 12$ billion in 2011. Worldwide, the civilian private security industry was estimated to be worth $\$ 165$ billion in 2009 , and is likely to be worth $\$ 244$ billion by 2016, with annual growth in the region of $7 \%$.

\footnotetext{
${ }^{3}$ It needs to be stressed that PSCs in Ghana are overwhelmingly urbanbased, with about $76 \%$ of the officially registered PSCs located in the national capital, Accra. This is partly due to the fact that large cities such as Accra account for a disproportionate share of all reported cases of crime.

4 UNODC (2014) notes that in a number of countries (notably Britain and Northern Ireland, USA and Israel) the budgets of PSCs and the number of personnel employed exceed those of the public police. In some cases, the staggering numbers of PSCs' employed have altered significantly the private security to police ratio such as in India where the ratio is estimated to be as high as almost 5 to 1 .
} 
Table 2 Selected information on PSCs in selected countries/regions

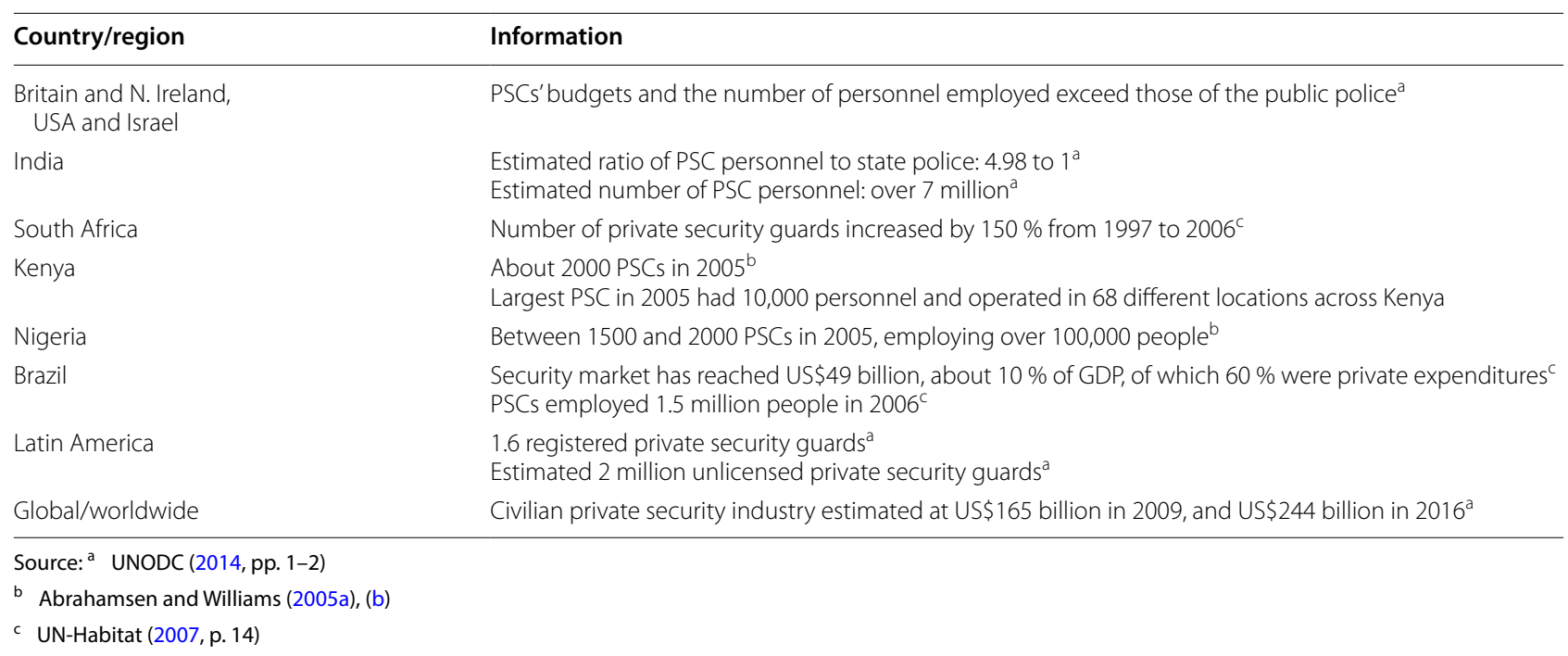

According to UNODC (2014), although reasons for the growth of PSCs vary, they are centred on fear of crime and the public police's inability to provide the security services that people, businesses and other organizations' need. This situation is more so in developing countries where rapid urbanization and associated urban sprawl have brought to the fore the challenges of security and safety of communities. Consequently, increasing crime and fear of crime plus weak capacity of the public police provide the justification for households and communities to seek the services of PSCs. Baker (2009) adds that in many developing countries, state security and justice systems (whether reformed or not) are not going to offer an effective and accessible service for the majority of the population in this generation or the next due to resource constraints, corrupt and abusive practices and political interferences.

However, the rise of PSCs is made possible by the neoliberal economic and privatization policies of the state under the policy doctrine of shifting the burden of public goods provision (including security) to society (Lippert and O'Connor 2003; Chandler 2013). In other words, as GTUC, FES (2011) note the growing numbers of PSCs reflect the state's efforts at outsourcing of state's functions to the private sector. Lippert and O'Connor (2003) have argued that within the context of liberalization and privatization, the public sector itself is increasingly a consumer (rather than a producer) of security services, and hence justifying the proliferation of PSCs as well as the range of services they offer.

Many scholars of governance, politics and development have noted the role of actors other than the state in providing 'governance without government' (Rosenau and
Czempiel 1992; Holmqvist 2005). This has challenged the state's monopoly on the legitimate use of violence, including the sanctioning, control and use of force. An important part of this shift in terms of security governance is the inclusion of private security providers with clear corporate structures (Andrew et al. 2008; Chesterman and Fisher 2009; Graham 2010; Leander 2010; Abrahamsen and Williams 2011; Krahmann 2012). Indeed, as Shearing and Stenning (1981) and Lippert and O'Connor (2003) argue the growth of private security is a 'quiet revolution' which has coincided with the expansion and spread of mass private property such as shopping malls, office, recreational, industrial, and manufacturing complexes in urban settings, and increasing share of public life takes place on such privately-owned properties.

Related to the above, the concept of network analysis offers one way by which we can understand the existing multiple security and justice providers, and the complex relationships that they have with one another (Wasserman and Faust 1994; Johnston and Shearing 2003; Dupont 2006; Wood and Shearing 2007). This understanding sees a multiplicity of authorizers and providers of security and justice 'that co-exist in multiple ways to produce diverse security outcomes' (Wood and Shearing 2007, p. 13), and hence, the proliferation of PSCs. Related to the network analysis is the growth of the concept of third party policing defined as police efforts to persuade or coerce organizations, businesses, communities and individuals to take some responsibilities for preventing and reducing crime (see Buergera 1998; Buergera and Mazerolle 1998; Mazerolle and Ransley 2006; Desmond and Valdez 2012). Indeed, the growth of PSCs and third party policing in general can be placed within the context 
of the widespread implementation of new approaches that assign policing responsibilities to non-police actors (Desmond and Valdez 2012). ${ }^{5}$

Lastly, the public choice theory attempts to provide answers to the question of why individuals, households and other entities prefer the services of PSCs, and hence, the proliferation of these companies (Cséfalvay 2011). Within the thinking of public choice theory, good government policies, such as public policing, are pure public goods for the citizenry. However, there may be other actors/agents (usually in the minority) that have strong incentives for advocating and lobbying government to implement specific policies such as the privatization of security that would benefit these few at the expense of the majority. Writing on security and gated communities in Budapest, Hungary, Cséfalvay (2011) concludes that the zeal for prestige and good social status seems to exceed the fear of crime and the need for self-segregation as the main idea for moving into gated communities and the preference of private security.

In broad terms, many of the above explanations of the growth of PSCs are applicable in the Ghanaian case. As already noted, officially there were as many as 176 registered PSCs in Ghana in 2014, with several operating without license or permit. ${ }^{6}$ However, a recent press conference organized by the Association of Private Security Organizations, Ghana (APSOG) to rebut claims by the Ministry of Interior that it has no proper records of PSCs put the total number of PSCs registered at 1053 of which only 175 are in good standing and of these 70 are members of APSOG. ${ }^{7}$ According to UN-OHCHR (2013, p. 3-4), though there may be some disagreements on the current statistics, it is not in doubt, however, that the number of PSCs in Ghana has increased over the years. Indeed, many analysts of the Ghanaian security sector have noted the growth of PSCs as the logical extension of the economic liberalization and

\footnotetext{
${ }^{5}$ It must be noted that the growth of third party policing and PSCs in particular is not occurring in a vacuum but reflects partly 'the move from centralized control to a system of de-centred networks of governance and crime control agents' (Mazerolle and Ransley 2006, p. 2) within the general context of changing government and governance.

${ }^{6}$ A report cited in a publication by the Ghana Trades Union Congress (GTUC) and the Friedrich Ebert Stiftung (FES) notes that there were as many as 438 registered private security organizations in Ghana in 2006 (GTUC/FES 2011, p. 15).

${ }^{7}$ Interior Ministry has data on private security companies. http://news. peacefmoline.com/pages/news/201505/241811.php. Accessed on May 30, 2015. Also, several attempts by the authors of this article to seek data on the number of registered PSCs per year over the last 10 years through formal requests to the Ministry of Interior yielded no results. Instead the authors were provided with a list of 1,033 PSCs with no information as to when they were established and whether they are still operating or functional.
}

privatization efforts of the state which began in the mid1980s under the World Bank/IMF-supported Structural Adjustment Programmes (SAPs) initiative (GTUC, FES 2011).

Although the process of Ghana's association with globalization dates back into time, this process has been fast-tracked since the mid-1980s when the country adopted neoliberal economic policies under SAPs (Grant and Nijman 2002; Otiso and Owusu 2008; Grant 2009). These policies have created the space and structures for the influx of global capital into key sectors of the Ghanaian economy including security. Indeed, the list of registered PSCs in Ghana includes Group 4 Securicor (G4S), a leading global multinational PSC operating in 26 African countries and 110 countries globally. The presence of these PSCs have been partly driven by the influx of global capital into sectors such as real/housing estates (especially gatedcommunities), mining, marine/aviation, shopping malls, and hotels. ${ }^{8}$

The implementation of neoliberal economic policies has coincided with an era of rapid urbanization and urban sprawl, especially in large Ghanaian cities such as Accra, Kumasi, Sekondi-Takoradi and Tamale. According to Cohen (2004), contemporary urbanization trends in many developing countries are strongly characterized by an unprecedented scale of urban change, which is more strongly influenced by globalization than ever before. Furthermore, globalization has the tendency to favour the concentration of capital and economic activities in large cities such as Accra and Kumasi (Owusu 2008; Owusu and Oteng-Ababio 2015). This inevitably exacerbates inequalities across cities as large cities tend to attract more investments and population which strengthen their growth and expansions, and hence, the opportunities for private security. Consequently, the police and other security agencies of the state are unable to reach all sections of cities-providing a perfect opportunity for PSCs to step in to provide security, especially for the growing middle and upper-classes of the population. As Wegener (2011, p. 6) notes the growing middle-class in Ghana is beginning to 'see it as a necessity and normality to have electric fencing around their properties and the demand for private security companies in Ghana is skyrocketing'.

\footnotetext{
${ }^{8}$ It needs to be stressed that overwhelming majority of PSCs in Ghana are owed and run by Ghanaians, mainly former senior police and military officers, and usually with good connections to the upper echelons of power. This obviously raises a lot of questions particularly regarding the process of registering companies and operations of unregistered PSCs, a subject matter which is explored in subsequent sections of this article.
} 
Table 3 Selected communities: survey sample allocation and number of KIls

\begin{tabular}{lllc}
\hline City & Community & $\begin{array}{l}\text { Community } \\
\text { socio-economic status }\end{array}$ & $\begin{array}{l}\text { Households } \\
\text { sampled }\end{array}$ \\
\hline Accra & Airport West & Upper-class & 30 \\
& Dansoman & Middle-class & 300 \\
& Glefee-Dansoman & Low-class & 60 \\
& Nima & Low-class & 510 \\
Kumasi & Ahodwo & Upper-class & 60 \\
& Oforikrom & Middle-class & 465 \\
Sekondi-Takoradi & Aboabo & Low-class & 360 \\
& Chapel Hill & Upper-class & 165 \\
& Anaji Estate & Middle-class & 135 \\
Tamale & New Takoradi & Low-class & 210 \\
& Russian Bungalow & Upper-class & 45 \\
Total & Zogbeli & Middle-class & 225 \\
\hline
\end{tabular}

\section{Methods}

This study is based on a mixed methodological approach involving the use of qualitative data, mainly key informant interviews (KIIs) and a household survey as part of a broader study that seeks to explore the nexus between crime and poverty in urban Ghana. Both the interviews and survey covered issues relating to city and neighborhood crime types, incidence, and the causes and effects of crime. More importantly, they also include questions on PSCs in crime prevention and services rendered by PSCs. In addition, the KIIs explored the relationship between PSCs and the police, and the effectiveness of the PSCs in crime prevention.

This study was undertaken in four key cities in Ghana, namely, Accra, Kumasi, Sekondi-Takoradi and Tamale. These four cities represent the key metropolitan centres in Ghana, and account for about $40 \%$ of the total urban population of the country (Owusu et al. 2015). In each city, the study focuses on three socio-economic neighborhoods with distinct characteristics (low-class, middle-class and upper-class residential communities). In all, the study covered 13 selected communities as shown in Table $3 .^{9}$ Primary data collection was done in two

\footnotetext{
9 The communities were selected based on the researchers' knowledge of these communities as well as classification of urban neighborhood into three distinct characteristics of low, middle and upper-class neighborhoods by earlier studies (see Benneh et al. 1993; Songsore et al. 1998, 2005; AgyeiMensah and Owusu 2010; Owusu and Agyei-Mensah 2011). This selection process was validated by key stakeholders such as the city planners, police and local government representatives (popularly referred to as Assembly Members) during initial project reconnaissance visits to the selected cities.
}

phases. Phase one involved conducting KIIs among senior police/crime officers of the Ghana Police Service; city planners/administrators, NGOs and traditional/ religious/opinion leaders. In all, 50 KIIs were conducted in all the four cities. Insights obtained from the qualitative study were used to develop a household questionnaire survey for phase two. In all, 2745 households were sampled in all the selected communities in the four cities. ${ }^{10}$

\section{Results}

In the following, the key findings of the study are discussed in respect of the article's objectives as set out in the background section:

\section{Policy, institutional and legal framework of private security in Ghana}

The existing policy, institutional and legal framework of Ghana provides the list of key actors in the country's

\footnotetext{
${ }^{10}$ Assisted by the Ghana Statistical Service (GSS), the official agency incharge of census and other public surveys in Ghana, the sample design was a clustered, multi-stage probability sample based on a list of enumeration areas (EAs) that was used for Ghana's 2010 Population and Housing Census by the GSS. The random selection of households for the survey was achieved by two stage processes: first, EAs were selected through the probability proportional to size (PPS method) based on each city's share of the total population of the four cities involved in the study. Afterwards, each city's share of EAs were subsequently proportionally distributed among the selected neighborhoods based on each neighborhood's population. At the second stage, 15 households and their respective household heads or knowledgeable adult representatives of the households were selected systematically in each EA, with a random start and interval separately for each EA to produce a total of 2745 households for the four cities (Accra, Kumasi, Sekondi-Takoradi and Tamale).
} 
security regulations and oversight, namely, the Ghana Police Service (GPS), Armed Forces, Immigration Service and Customs Excise and Preventive Unit of the Ghana Revenue Authority (GRA). Others include the state intelligence agency, the Bureau for National Investigation (BNI) and related agencies; judicial and penal services, that is, the Ghana Prisons Service and Judiciary Service; cabinet//Parliament; private sector and; civil society (including traditional authority and NGOs). Clearly, as Abudu et al. (2013, p. 12) note 'the security landscape in Ghana is diverse and not homogenous, with various actors operating outside the state mechanism to provide security to various segments of the population.

The registration, regulation and monitoring of PSCs are the responsibilities of the Ministry of Interior and the Ghana Police Service. In fact, a review of existing legal regulations of PSCs shows that the attempts by the state to promote and regulate the private security sector dates back to the early 1970s with the promulgation of Section 38 of the Police Service Act of 1970 (Act 350). This represents the state's initial attempt to define the parameters for regulating non-statutory security actors like PSCs. ${ }^{11}$ Nothing by way of legislation or policy was introduced by the state to promote PSCs after 1970 until the early 1990s, when Act 350 was amended with Legislative Instruments 1571 of 1992 and 1579 of 1994. These Legislative Instruments (LIs) provide the process for the registration, vetting and granting of license to security organizations; approval of uniform/cloth and other accoutrements to be used by private security organizations (which must not bear resemblance to those used by the state's security agencies); restrictions on the use of fire arms and; renewal of license/certificate of operation. These legal instruments govern the activities of registered commercial private security organizations as well as informal organization such as neighbourhood watchdog committees.

According to ASDR (2008) 'as of now, the private security sector is controlled by the Police Service Act of LI 1571 which lacks a lot of detail so far as management of the sector is concerned, resulting in the need to find a more comprehensive and adequate legislative instrument to consolidate the security of the state'. It adds that a key missing link in the existing legal and policy regime is the absence of a dedicated regulatory authority located either within the Ministry of Interior or the Ghana Police Service. As a key informant in the sector noted:

\footnotetext{
${ }^{11}$ Indeed, Section 38 of Act 350 came about as a result of the then government, Progress Party's (PP) pro-capitalist and privatization-orientations. However, the PP government had a short stay in power as it was overthrown in a military coup in 1972, and this ended its privatization and procapitalist agenda.
}

At the moment, the Ministry of Interior is supposed to regulate activities of private security companies but the Ministry is not doing this. We need a dedicated unit within the Ministry to do this... For a long time, even having a Desk Officer at the Ministry has been a problem. At a point, we had a Desk Officer who was only in charge of refugees' issues and also acted as an Officer for the private security, who very often was not available. He was always out. Now, there is someone who is at the Minister's office, whom we are told is the Desk Officer for Private Security but what is his or her role?.... And so, more or less he takes complains or reports to the Minister and also passes on any communication that the Ministry would like to pass on to us [PSCs]. So that is his role but as to the real oversight responsibility, I don't think anybody [unit] is taking it up for now.

The above quote and evidence from the literature on PSCs in Sub-Saharan Africa suggest that it is common for private companies to be formally registered but rarely are they regularly monitored (see Baker 2009; Abrahamsen and Williams 2007, 2011; UNODC 2014; UN-OHCHR 2013). In the Ghanaian case, this situation partly accounts for the proliferation of PSCs as well as the presence of unregistered companies (UN-OHCHR 2013; ASDR 2008). On the other hand, ASDR (2008) partly blamed the non-registration of PSCs in Ghana on long delays in the granting of licenses/permits and the lack of transparency in the registration process. For instance, Section 12(1) of LI 1571 states clearly that no employee of an organization licensed under the LI shall wear, carry or bear any uniform, cap, badge, accoutrements or other identification mark unless these have been approved for use by the Inspector-General of Police in writing. However, in recent times the Ghana Police Service have had to issue several directives in the media to stop this practice as several PSCs and other organizations have flouted this regulation. ${ }^{12}$

The inability of the Ministry of Interior and the Police Service to adequately regulate PSCs partly accounts for the formation of APSOG in 1998. APSOG is a voluntary association of PSCs which seeks to promote the interest of the industry and to ensure its regulation to enable it work effectively with all stakeholders. It also seeks to promote standardization of training within the private security industry and also to serve as the industry's mouthpiece. However, APSOG is a voluntary association and membership is not compulsory. In addition, it has

\footnotetext{
12 Stop wearing unapproved uniforms-Police http://www.graphic.com.gh/ news/general-news/22576-stop-wearingunapproved-uniforms-police.html; http://www.ghanamma.com/stop-wearing-unapproved-uniforms-police. Accessed on May 20, 2015.
} 
Table 4 Reasons for springing up of PSCs by city

\begin{tabular}{|c|c|c|c|c|c|}
\hline \multirow[t]{2}{*}{ Reason } & \multicolumn{5}{|c|}{ Selected cities } \\
\hline & Accra & Kumasi & Takoradi & Tamale & Total \\
\hline Job creation drive/business motive & 18.7 & 14.3 & 28.4 & 22.0 & 21.6 \\
\hline Complimentary efforts to enhance communal security & 18.7 & 26.2 & 15.0 & 4.9 & 18.1 \\
\hline Absence of public security set-up & 16.5 & 17.3 & 18.1 & 4.9 & 16.7 \\
\hline Loss of confidence in public security & 21.1 & 11.9 & 8.4 & 26.8 & 14.8 \\
\hline Over-population with an unmet security needs & 10.9 & 13.1 & 12.5 & 29.3 & 12.8 \\
\hline Community self-help initiative & 9.7 & 10.1 & 1.3 & 0.0 & 6.1 \\
\hline Came alongside a multinational company & 1.9 & 5.4 & 11.6 & 0.0 & 6.1 \\
\hline Affordability/tailor-made services & 2.5 & 1.1 & 2.8 & 12.2 & 2.8 \\
\hline Other & 0.0 & 0.6 & 1.9 & 0.0 & 0.8 \\
\hline Total & 100.0 & 100.0 & 100.0 & 100.0 & 100.0 \\
\hline
\end{tabular}

Source: Household questionnaire survey, 2014

no hand in the licensing and renewing of the permits of PSCs. As a result, few PSCs have joined the association which started with 25 PSCs, but with current membership of about 100, although APSOG acknowledged that there are over 1000 PSCs in Ghana.

With the above assessment of the policy, institutional and legal framework of PSCs, what are households' perception about the role of PSCs in preventing and reducing crime in urban Ghana? Based on mainly analysis of the results of household questionnaire survey and key informant interviews in the selected cities and communities, the next section attempts to provide answers to this question.

\section{Households' perceptions of PSCs in Ghana}

Our analysis of the household survey results indicate that $12.6 \%$ of the 2745 households surveyed in the four cities of Accra, Kumasi, Sekondi-Takoradi and Tamale had knowledge on whether PSC operates in their communities. This is, however, relatively higher in the high-class neighborhoods (57 \%) compared to just $2.7 \%$ and then $12.7 \%$ in low-class and middle-class neighbourhoods respectively. This buttressed the view of Abudu et al. (2013) and Heyns and Steifiszyn (2006) that PSCs tend to be urban-focused and profit-motivated, and they target only the wealthier in society that are able to afford their services.

Tables 4 and 5 provide information on the reasons assigned by households as accounting for the proliferation of PSCs by city and neighbourhood socio-economic (SE) status. The results from the two tables are fairly similar. It is, however, interesting to note that job creation drive/business motive is seen among all the different socio-economic households and cities as the single key driver for PSCs' proliferation. Thus, for over 2 in 10 households and almost 3 in 10 in the case of Takoradi, job creation drive/business motive is regarded as the reason for the proliferation of PSCs rather than the complimentary efforts of these companies to enhance communal security and the absence or loss of confidence in public security. This result is very interesting given the fact that the literature has highlighted the complimentary role of PSCs in providing security due to the absence/ loss of confidence in public security and an ever-growing urban population with unmet security needs as the critical reasons accounting for the proliferation of PSCs (see Abrahamsen and Williams 2005a, b; UN-Habitat 2007; UNODC 2014).

Nevertheless, it needs to be stressed that when all the explicitly stated security drivers are put together as shown in Tables 4 and 5, unmet security needs of households account for the main reason for the proliferation of PSCs across the four cities and three different socio-economic neighbourhoods. In other words, when reasons such as complimentary efforts to enhance communal security; absence of public security set-up; loss of confidence in public security and; over-population with unmet security needs-are put together the security reason becomes the dominant reason for the proliferation of PSCs in line with the mainstream literature. Indeed, when the security reasons are put together about 6 in 10 households viewed the proliferation of PSCs as largely due to unmet public security needs. Nevertheless, the reference to jobs/business opportunities offered by PSCs according to the household survey remained significant as there is relatively little reference to it in the private security and crime literature.

Although PSCs are seen as a major source of employment for young and unskilled workers, a recent comprehensive report on the wages and working conditions of workers of PSCs in four regions of Ghana (Greater Accra, Western, Ashanti and Northern Regions) concludes that 
Table 5 Reasons for proliferation of PSCs by neighbourhood socio-economic status

\begin{tabular}{lrrrrr}
\hline Reason & \multicolumn{5}{c}{ Community SE status } \\
\cline { 2 - 6 } & Low & Middle & High & Total \\
\hline Job creation drive/business motive & 19.4 & 19.8 & 22.6 & 20.9 \\
$\begin{array}{l}\text { Complimentary efforts to enhance } \\
\quad \text { communal security }\end{array}$ & 14.6 & 16.6 & 20.8 & 18.1 \\
Absence of public security set-up & 9.7 & 21.1 & 15.5 & 17.3 \\
Loss of confidence in public security & 18.4 & 18.7 & 8.9 & 14.6 \\
$\begin{array}{l}\text { Over-population with an unmet security } \\
\quad \text { needs }\end{array}$ & 19.5 & 11.3 & 13.2 & 13.0 \\
Community self-help initiative & 8.7 & 4.8 & 7.1 & 6.3 \\
Came alongside a multinational & 2.9 & 4.8 & 8.9 & 6.3 \\
$\quad$ company & & & & \\
Affordability/tailor-made services & 5.8 & 2.4 & 1.8 & 2.6 \\
Other & 1.0 & 0.5 & 1.2 & 0.9 \\
Total & 100.0 & 100.0 & 100.0 & 100.0 \\
\hline
\end{tabular}

Source: Household questionnaire survey, 2014

these workers are poorly remunerated (GTUC, FES 2011). ${ }^{13}$ The report adds that 'while the preponderance of low pay in the private security industry is not isolated, it also reflects to a very large extent, the low level of education of workers in the industry. Majority of the workers have only had junior and senior level of education' (GTUC, FES 2011, p. 24). The low wages and poor working conditions of employees as noted in the report is of great concern since it can impact negatively on crime prevention. ${ }^{14}$

Our analysis of the household survey results indicate that across the four cities and the different socio-economic neighbourhoods, households have a fairly good knowledge of the different types of security services provided by PSCs. For instance, though very few households in low-class neighbourhoods have any knowledge of PSCs operating in their neighbourhoods, however, these households were able to identify the keys services provided by PSCs: guard public servants/firms/property; guard private servants/firms/property; provide surveillance system and; collaborate with state security for community protection. These results obtained from the low-class communities were fairly similar to those of the

\footnotetext{
13 The GTUC/FES (2011) study found the average gross monthly income of PSC personnel to be approximately GH\$150.00 (about US\$94 at the end of 2011 exchange rate of about GH41.6 to US\$1). This monthly gross income of PSCs largely remain unchanged in dollar terms at current exchange rate of about GH $\$ 4$ to US\$1.

14 Reports already exist in the Ghanaian media of either the direct or indirect involvement of employees of PSCs in criminal activities, including armed robbery and burglary. As a former Interior Minister noted in a report 'what remains a source of concern to our Ministry are reports to the police of illegal activities involving employees of PSCs' (ASDR 2007, p. 8).
}

middle and upper-class communities which employ the services of PSCs. ${ }^{15}$ The good knowledge of households about the services offered by PSCs may reflect the profound presence of PSCs in key Ghanaian cities as their numbers and services have increased over the years.

Table 6 provides the results of what households consider as the benefits of PSCs. Interestingly and similar to the reasons assigned by households for the proliferation of PSC, the provision of employment or jobs top the list of benefits. ${ }^{16}$ Table 6 shows that even for high-class residential neighbourhoods which demand the services of PSCs most, households placed the creation of jobs as a benefit of PSCs above improved household and community security. Indeed, similar observations can be made when the data is aggregated by city. Across the study cities and the different socio-economic neighbourhoods within these cities, interviews suggest close correlation between lack of employment and crime. As a Planning Officer in Sekondi-Takoradi noted:

You know usually majority of these people who engage in crime are the youth who don't have work to do.... So when people are employed, then the tendency for them to engage in crime is very minimal.... It is said that the devil finds work for the idle hand. Most of the people who engage in crime are people who usually don't have jobs.

The above quotation and the general sentiments expressed regarding the importance of unemployment as a predisposition factor to criminal activities possibly account for the results in Table 6. Even though studies have indicated that staff of PSCs are poorly paid, PSCs remained a vital source of employment for lowly-educated and unskilled young people (GTUC, FES 2011). Although the actual number of staff employed by PSCs in Ghana is difficult to ascertain, it can be estimated that with a conservative figure of 450 PSCs in the country, the number of people employed by these companies run into thousands. For instance, UT Private Security Services Limited (UTPSSL), a Ghanaian-owned company operated with a total staff strength of over 400 in January 2013. Certainly, UTPSSL is not the largest PSC in Ghana, but its staff strength gives an indication of the total

\footnotetext{
${ }^{15}$ Although low-class households rarely employed the services of PSCs, the relatively good knowledge of the services provided by these companies among these households may be probably due to the high presence of PSCs employees in these communities. As earlier noted, PSCs' employees tend to be lowly-educated and poorly paid - employees who fit the description of the majority of individuals and households residing in low-class communities.

16 As earlier noted for the reasons accounting for the proliferation of PSCs, if the security-related benefits are put together, improved security is the main benefit of PSCs to households.
} 
Table 6 Benefits of PSCs to the household/community by SE status

\begin{tabular}{lrrrr}
\hline Benefits & \multicolumn{4}{c}{ Community SE status } \\
\cline { 2 - 5 } & Low & Middle & High & Total \\
\hline Created jobs & 22.1 & 23.6 & 22.9 & 23.1 \\
Improved household security & 15.4 & 24.6 & 22.3 & 22.5 \\
Improved community security & 18.3 & 16.3 & 20.2 & 18.2 \\
Improved industrial/commercial security & 17.3 & 14.0 & 19.1 & 16.6 \\
Improved crime prevention efforts & 18.3 & 11.9 & 9.0 & 11.4 \\
Complimented police efforts & 7.7 & 7.0 & 4.9 & 6.2 \\
Other & 1.0 & 2.3 & 1.5 & 2.0 \\
Total & 100.0 & 100.0 & 100.0 & 100.0 \\
\hline Surcery & & & &
\end{tabular}

Source: Household questionnaire survey, 2014

Table 7 Challenges of PSCs to household/community by SE status

\begin{tabular}{lrrrr}
\hline Challenges & \multicolumn{3}{c}{ Community SE status } & \\
\cline { 2 - 5 } & Low & Middle & High & Total \\
\hline Increased household expenditure & 21.9 & 23.4 & 35.3 & 28.8 \\
$\begin{array}{l}\text { Increased industrial/companies' } \\
\quad \text { expenditure }\end{array}$ & 18.8 & 15.9 & 33.3 & 24.3 \\
$\begin{array}{l}\text { Weakened/compromised household } \\
\quad \text { security }\end{array}$ & 18.8 & 22.1 & 7.7 & 15.0 \\
$\begin{array}{l}\text { Weakened/compromised } \\
\quad \text { neighbourhood security }\end{array}$ & 15.6 & 11.0 & 8.3 & 10.2 \\
$\begin{array}{l}\text { Duplicating police effort } \\
\text { Allowed criminals to infiltrate }\end{array}$ & 12.5 & 7.6 & 4.5 & 6.6 \\
$\quad$ neighbourhood & 9.3 & 6.9 & 3.2 & 5.4 \\
$\begin{array}{l}\text { Increased crime occurrence } \\
\text { Other }\end{array}$ & 3.1 & 4.8 & 1.9 & 3.3 \\
\begin{tabular}{l} 
Total \\
\hline
\end{tabular} & 0.0 & 8.3 & 5.8 & 6.3 \\
\hline
\end{tabular}

Source: Household questionnaire survey, 2014

number of people employed in the private security industry in the country. ${ }^{17}$

Table 7 provides information regarding households' opinions on the challenges of PSCs to households and communities by socio-economic status. According to Table 7, the key challenge to households and communities is that PSCs tend to increase household expenditure. This view is strongest among high-class communities where $35.3 \%$ of households hold this view. Similarly, the services of PSCs are regarded by households as

\footnotetext{
17 Assuming conservatively on the average each of the 450 PSCs employed between 50 and 100 staff, guesstimates will put the total number of employees of PSCs between 22,500 and 45,000. These guesstimated figures come closer or exceed the staff strength of the state's police which stood at 29,117 in 2012 (NDPC 2013). According to NDPC (2013), Ghana's Police-Population Ratio (PPR) of 1:847 in 2012 remains far from the United Nations' policing standard of 1:500 PPR.
}

contributing to increase expenditure of firms/industries. Interestingly, about 1 in 10 households viewed the services of PSCs as weakening or compromising the security of household and community. This view was relatively stronger in the low and middle-class neighbourhoods compared to the upper-class neighbourhoods. Other challenges identified to a limited degree are duplicating police effort; allowing criminals to infiltrate neighbourhoods and; increasing crime occurrence.

Table 7 suggests that a substantial proportion of households, particularly in low and middle-class neighbourhoods, viewed PSCs as not enhancing security and reducing crime but rather compromising household and neighbourhood crime fighting efforts. In all, Table 7 suggests that nearly $50 \%$ of households viewed PSCs as compromising household and community security. This proportion is, however, relatively higher for low and middle-class neighbourhoods. Indeed, households' views of PSCs as weakening household and community security; allowing criminals to infiltrate neighbourhood; increasing crime occurrence and; duplicating police efforts, do not present a good image of PSCs. This suggests that not all households see the services of PSCs as complementing the efforts of the state in terms of security and the prevention of crime. However, the complementary role of PSCs is critical in the face of the public police's inability to meet the security needs of households. As a senior Police Officer noted:
I think private security companies are very useful and many of them are needed in the system. They [private security] are effective as when they are around scarcely will crime take place unless they compromise their position. This is because criminals don't want somebody to see what they're doing and that is the nature of bad people... The mere presence of private security at a location can deter crime.

\section{Conclusion and policy implications}

Similar to the situation across many countries in SubSaharan Africa and other parts of the developing world, the private security industry has seen significant growth in recent decades in Ghana. This situation has been aided by Ghana's privatization policies, and an ever-growing urban population with unmet security needs. Within this context, the country has witnessed the proliferation of PSCs as the demand for security services has soared due to increased global capital investments and an evergrowing middle-class. However, the formal regulation of Ghana's private security sector remained weak-in an industry described by Percy (2012, p. 941) as 'agile and innovative, and has responded swiftly to changing market pressures'. Consequently, many PSCs remained beyond 
the radar of state regulations with serious implications for security and efforts to fighting crime.

PSCs in Ghana remained urban-focused, with many of them concentrated in the capital, Accra, targeting middle and upper-class households where their services are mostly patronized. However, contrary to the wellrehearsed reasons cited in the literature as accounting for their proliferation, a survey of households in low, middle and upper-class neighbourhoods in key Ghanaian cities cite job creation/business motive as the single key reason for the proliferation of PSCs. Similarly, they cite job creation as the key benefit of PSCs to households and communities, ahead of security considerations. Nevertheless, the survey results show that when the security-related reasons are put together, the need to improve security remains the key driver for the proliferation of PSCs and the benefits derived by households for the services of these companies. Furthermore, households identify the services of PSCs as contributing to increased household and firm expenditure as well as weakened and compromising household and community security.

Ghana is undergoing a process of urbanization with rapid shifting of the country's population from rural to urban areas. However, the process is unplanned resulting in uncontrolled sprawl which stretches infrastructure and services (including police services). With rising crime incidence, providing security for all sections of the population should be part and parcel of any discussions of Ghana's urban future. Indeed, there is the need to better regulate PSCs through amending the existing legal regime to properly complement the efforts of the Ghana Police Service and other security agencies of the state with the overall aim of promoting a safe and an inclusive urban development for all (including the poor). It is within this context that identifying PSCs and their areas of operations properly and a dedicated oversight authority become a matter of importance in terms of the regulation of these private companies by the state. Clearly, a good knowledge of PSCs by the state provides opportunities not only for monitoring their activities but also promoting joint actions and collaborations for the purpose of maintaining security and securing the urban environment. Indeed, all indications suggest that the PSCs have come to stay as the underlying factors for their growth and proliferation are not likely to go away soon. It is therefore important that challenges confronting the private security industry in Ghana are addressed to enhance the complementary role of the industry in providing security for neighbourhoods.

\section{Authors' contributions}

Authors were part of the data collection. All authors read and approved the final manuscript.

\section{Acknowledgements}

This work was carried out with the financial support from the UK Government's Department for International Development (DFID) and the International Development Research Centre (IDRC), Ottawa, Canada. However, the views expressed in this presentation are solely those of the authors.

\section{Competing interests}

The authors declare that they have no competing interests.

Received: 3 July 2015 Accepted: 4 April 2016

Published online: 14 April 2016

\section{References}

Abrahamsen, R., \& Williams, M. C. (2005a). Globalisation of private security: Country Report Kenya (January 2005) 3. Aberystwyth: Department of International Polititcs, University of Wales.

Abrahamsen, R., \& Williams, M. C. (2005b). Globalisation of private security, Country Report: Nigeria (January, 2005) 3. Aberystwyth: Department of International Polititcs, University of Wales.

Abrahamsen, R., \& Williams, M. C. (2007). Securing the city: private security companies and non-state authority in global governance. International Relations, 21(2), 237-253.

Abrahamsen, R., \&Williams, M. C. (2011). Security beyond the state: Private security in international politics. Cambridge: Cambridge University Press.

Abudu, A. M., Nuhu, Y., \& Nkuahet, J. K. (2013). Bridging the security gap in Ghana: the role of private security actors. Developing Country Studies, $3(10), 11-30$.

Agyei-Mensah, S., \& Owusu, G. (2010). Segregated by neighbourhoods? a portrait of ethnic diversity in the neighbourhoods of the Accra metropolitan area, Ghana. Population, Space and Place, 16(6), 499-516.

Andrew, A., Deane-Peter, B., \& Caparini, M. (2008). Private military and security companies: ethics, policies and civil-military relations. London: Routledge.

ASDR (African security dialogue and research). (2007). Rapporteur's report on the fourth parliamentary training workshop on understanding and regulating private security in Ghana. Accra: ASDR.

ASDR (African security dialogue and research). (2008). Report of the workshop on the state of the private security service providers in Ghana, 23rd July, 2008, Mensvic Hotel, East Legon-Accra. Accra: ASDR.

Baker, B. (2009). Security in post-conflict Africa: the role of non-state policing. Boca Raton: CRC Press.

Benneh, G., Songsore, J., Nabila, J. S., Amuzu, A. T., Tutu, K. A., Yangyuoru, Y., \& McGranahan, G. (1993). Environmental problems and the urban household in the greater Accra metropolitan area (GAMA). Ghana. Stockholm: Stockholm Environment Institute.

Buergera, M. E. (1998). The politics of third-party policing. Crime Prevention Studies, 9, 89-116.

Buergera, M. E., \& Mazerolle, L. G. (1998). Third-party policing: a theoretical analysis of an emerging trend. Justice Quarterly, 15(2), 301-327.

Chandler, D. (2013). 'Resilience and the autotelic subject: toward a critique of the societalization of security. International Political Sociology, 7(2), $210-226$.

Chesterman, S., \& Fisher, A. (2009). Private security, public order: the outsourcing of public services and its limits. Oxford: Oxford University Press.

Cohen, B. (2004). Urban growth in developing countries: a review of current trends and a caution regarding existing forecasts. World Development, 32, 23-51.

Cséfalvay, Z. (2011). Gated communities for security or prestige? a public choice approach and the case of Budapest. International Journal of Urban and Regional Research, 35(4), 735-752.

Desmond, M., \& Valdez, N. (2012). Unpolicing the urban poor: consequences of third-party policing for inner-city women. American Sociological Review, doi:10.1177/0003122412470829.

Dupont, B. (2006). Power struggles in the field of security: implications for democratic transformation. In B. Dupont \& J. Woods (Eds.), Democracy, society and the governance of security. Cambridge: Cambridge University Press. 
Farrell, G., Tilley, N., Tseloni, A., \& Mailley, J. (2010). Explaining and sustaining the crime drop: clarifying the role of opportunity-related theories. Crime Prevention and Community Safety, 12, 24-41.

Farrell, G., Tseloni, A., Mailley, J., \& Tilley, N. (2011). The crime drop and the security hypothesis. Journal of Research in Crime and Delinquency, 48(2), $147-175$.

Graham, S. (2010). Cities under Siege: the new military urbanism. London: Verso.

Grant, R. (2009). Globalizing city: the urban and economic transformation of Accra. Ghana. New York: Syracuse University Press.

Grant, R., \& Nijman, J. (2002). Globalization and the corporate geography of cities in the less developed world. Annals of the Association of American Geographers, 92, 320-340.

GTUC/FEES. (2011). Wages and working conditions of private security workers in Ghana. Accra: GTUC/FEES.

Heyns, C., \& Steifiszyn, K. (2006). Human rights, peace and justice in Africa: a reader. Pretoria: University of Pretoria Press.

Holmqvist, C. (2005). 'Private security companies: the case for regulation'. SIPRI Policy Paper, No. 9.

Johnston, L., \& Shearing, C. (2003). Governing security: explorations in policing and justice. London: Routledge.

Krahmann, E. (2012). From 'mercenaries' to 'private security contractors': the (re) construction of armed security providers in international legal discourses. Millennium: Journal of International Studies, 40(2), 343-363.

Leander, A. (2010). The paradoxical impunity of private military companies: authority and the limits to legal accountability. Security Dialogue, 41(5), 467-490.

Lippert, R., \& O'Connor, D. (2003). Security assemblages: airport security, flexible work, and liberal governance. Alternatives: Global, Local, Political, 28(3), 331-358.

Mazerolle, L., \& Ransley, J. (2006). Third Party Policing. Cambridge: Cambridge University Press.

NDPC (National Development Planning Commission). (2013). The implementation of the Ghana Shared Growth and Development Agenda (GSGDA), 2010-2013: 2012 Annual Progress Report. Accra: NDPC.

Otiso, M. K., \& Owusu, G. (2008). Comparative urbanization in Ghana and Kenya in time and space. GeoJournal, 71(2/3), 143-157.

Owusu, G. (2008). Indigenes' and migrants' access to land in peri-urban areas of Ghana's largest city of Accra. International Development Planning Review (IDPR), 30(2), 177-198.

Owusu, G., \& Oteng-Ababio, M. (2015). Moving unruly contemporary urbanism toward sustainable urban development in Ghana by 2030. American Behavioral Scientists (ABS), 59(3), 311-327

Owusu, G., Wrigley-Asante, C., Oteng-Ababio, M., \& Owusu, A. Y. (2015). Crime prevention through environmental design (CPTED) and built-environmental manifestations in Accra and Kumasi, Ghana. Crime Prevention and Community Safety, 17(4), 249-269.

Percy, S. (2012). Regulating the private security industry: a story of regulating the last war. International Review of the Red Cross, 94(887), 941-960.
Rosenau, J. N., \& Czempiel, E. O. (1992). Governance without Government: order and change in world politics. Cambridge: Cambridge University Press.

Shearing, C. D., \& Stenning, P. C. (1981). Modern private security: its growth and implications. Crime and Justice, 3, 193-245.

Songsore, J., Nabila, J. S., Amuzu, A. T., Tutu, K. A., Yangyuoru, Y., McGranahan, G., \& Kjellen, M. (1998). Proxy indicators for rapid assessment of environmental health status of residential areas: the case of the Greater Accra Metropolitan Area (GAMA), Ghana. Stockholm: Stockholm Environment Institute.

Songsore, J., Nabila, J. S., Yangyuoru, Y., Amuah, E., Bosque-Hamilton, E. K., Etsibah, K. K., et al. (2005). State of environmental health report of the greater Accra metropolitan area (GAMA), Ghana. Accra: Ghana Universities Press.

The Daily Graphic (2014). Licensed private security organizations (PSOs) in good standing with the Ministry as at 31st Oct, 2014, 4 Dec, 2014, 24-25.

UN-Habitat. (2007). Enhancing urban safety and security: global report on human settlements. Nairobi: UN-Habitat.

UNODC (United Nations Office of Drugs and Crime). (2014). State regulation concerning civilian private security services and their contribution to crime prevention and community safety. New York: United Nations.

UN-OHCHR (UN office of the high commissioner for human rights) (2013). Status report on Anglophone Africa comprehensive study and analysis of national legislation: Ghana, Mauritius, Sierra Leone, and The Gambia Nigeria, Uganda, Kenya. http://www.ohchr.org/EN/HRBodies/HRC/ RegularSessions/Session24/Documents/A-HRC-24-45_en.pdf.

Van Dijk, J., Tseloni, A., \& Farrell, G. (2012). The international crime drop: new directions in research. Basingstoke: Palgrave Macmillan.

Wasserman, S., \& Faust, K. (1994). Social network analysis. Cambridge: Cambridge University Press.

Wegener, K. (2011). 'Etuo mu ye sum: the barrel of a gun is dark'. Clouded in darkness: reflections on the uncertain future of small arms and light weapons in Ghana. Accra: Friedrich-Ebert-Stiftung.

Wood, J., \& Shearing, C. (2007). Imagining security. Cullompton: Willan Publishers.

\section{Submit your manuscript to a SpringerOpen ${ }^{\odot}$ journal and benefit from:}

- Convenient online submission

- Rigorous peer review

- Immediate publication on acceptance

- Open access: articles freely available online

- High visibility within the field

- Retaining the copyright to your article

Submit your next manuscript at springeropen.com 